\title{
A triangle of paradoxes. Gaceta Médica de México will only be electronically published
}

\author{
Alejandro Treviño-Becerra* \\ Academia Nacional de Medicina, Gaceta Médica de México
}

To try to find a satisfactory explanation, I consider that three events occur, converging like a scalene triangle, with uneven sides, at whose center is the Gaceta Médica de México editorial body:

1. On one side, the current situation of the country, with expenditure reduction policies undertaken by the presidency of the Republic.

2. On another, the isolated work sometimes the journal's management and editors carry out.

3. On a third side, the paradigm of modernity, which day after day brings us to ambivalent territories and that have no end. Probably, in a short time, another media will appear that will render the Internet obsolete, as the Internet is making with printing.

With regard to the first point, the National Academy of Medicine of Mexico has a voice in the Council of General Public Health.

Regarding the second point, the Gaceta editorial bodies have had autonomy to develop their editorial activity, but they depend economically on the National Academy of Medicine of Mexico and the journal occupies a highly important place in the Academy expenditure for the costs of publishing, translation and distribution, coupled with not being specified if the annuity paid by new joining academicians and numerary members covers the Gaceta copies.

The third one refers to Gaceta modernization and inclusion in electronic environments, which began in 2008 with simultaneous online publishing and continued with the electronic edition in English since 2014, to which editorial professionalization was added with the services provided by the Permanyer publishing company. All this has implied a progressive elevation in costs. On the other hand, the journal increased the number of pages to 144 and the print run to 2000 copies and, in the last three years, it has improved the cover design, some images are printed in color and the care of the edition has been professionalized, which has led to a larger number of colleagues aspiring to publish in this journal (in the first quarter of 2019, 147 manuscripts were received).

The paradox is that now that Gaceta has improved its printed version, which has been maintained throughout 154 years of existence, due to economic conditions and technological new paradigms, is nearing its end.

Let me recall that, in a 2017 survey, answered by 235 academicians, $86 \%$ stated they wanted to continue to receive the printed journal and maintain the online edition. In the symposium on National Medical Journals, at the Academy Congress in Monterrey, the trend of other connoted medical publications towards electronic format was clearly observed. At the beginning of March this year, by indication of the board of directors, I electronically submitted a one-question questionnaire, which was answered 148 academicians (those who are internet proficient): $25 \%$ stated they wanted to receive Gaceta Médica de México in printed form. In turn, the Academy management submitted a three-question questionnaire as well: out of 70 respondents, $25 \%$ expressed their desire for Gaceta Médica de México print edition to continue. Apparently, the number of academicians who do not want to receive the Gaceta hard copy is larger, which seems to contradict academicians' humanist spirit.

Experts will probably point out that the three surveys are methodologically deficient and that the questions are plain and direct; some academicians will ask if sampling was random, if the trend was sustained and whether with $10 \%$ of answers such an important decision can be made.
Gac Med Mex. 2019;155:202-203

Contents available at PubMed www.gacetamedicademexico.com 
In the search for opinions on the print run reduction or disappearance of the printed form of our journal, I consulted with previous editors of the journal: Dr. Francisco Olvera Esnaurrizar, who was associate editor in 1960 and 1961, remarked that the journal could not disappear and that we might as well ask each academician for five pesos a week or find a patron to preserve it. In turn, Dr. Silvestre Frenk (editor for 25 years) sent an e-mail expressing his feelings: "It seems to me that stepping into the digital era is an inevitable consequence of current times, even for Gaceta Médica de México. Thus, I have nothing else to say but that's the way things are."

Some of the received suggestions have pointed at reducing the print run, the number of pages, and the paper quality, or to collect shipping, insert commercial ads, charge more for supplements, reduce expenses; but nevertheless, none of these measures was sufficient to adjust the amount required to print at least 100 bimonthly copies, in addition to with other environmental and logistics issues.

I believe that the matter would deserve more participation of academicians themselves, both young and veterans, modernists or conservatives. Personally, I am in favor of lowering the production costs and maintaining a reduced paper edition of Gaceta Médica de México and I would not want for disgruntled voices to later appear censoring the disappearance of the printed version.

The results of this decision will be seen with the passage of years. The president of the National Academy of Medicine of Mexico and the editor may be remembered as those who canceled the Gaceta Médica de México printed form or as those who decided, moved by the above-mentioned circumstances about the scalene triangle, that in the future only the virtual magazine in Spanish and English will exist. The passage of time will show if there is to be a reduction or increase in the number of works submitted for publication and readers, as well as repercussions on the impact factor and other bibliometric indices. We must take care that our electronic journal doesn't get confused with the hundreds of online medical publications that proliferate day by day and even progressively increase without scientific foundation or editorial quality.

Current editors -editor in chief, executive editor, associate editors- continue working with enthusiasm and dedication in this transition period to preserve Gaceta Médica de México humanistic mission. 